\title{
Storage on the vigor and viability of macauba seeds from two provenances of Minas Gerais State
}

\author{
Tipo de armazenamento no vigor e na viabilidade de sementes de \\ macaúba oriundas de duas localidades do Estado de Minas Gerais
}

\author{
Patrícia Pereira de Souza ${ }^{\mathrm{I}}$ Sérgio Yoshimitsu Motoike ${ }^{\mathrm{I}}$ Mychelle Carvalho ${ }^{\mathrm{II}}$ \\ Kacilda Naomi Kuki ${ }^{\text {* }}$ Eduardo Euclydes de Lima e Borges ${ }^{I I I}$ Antônio Marcos Silva ${ }^{\mathrm{I}}$
}

\section{ABSTRACT}

Macauba palm stands out for having favorable features to biodiesel production such as the high oil content of its fruit. Considering the great potential of the species and their applicability in the renewable energy field, it becomes indispensable to establish the right conditions for storing the seeds for propagation purpose. The aim of this research was to evaluate the effect of seed moisture content, packaging, and storage conditions such as temperature and relative humidity on the quality of seeds from Minas Gerais State, during a 12-month storage period. The research had two independent assays: (I) the seeds were stored with three moisture contents/ranges $4.0 \leq 6.0 \% ; 6.0 \leq 8.0 \%$ and $8.0 \leq 10.0 \%$ in impermeable packages, under room temperature and at $10^{\circ} \mathrm{C}$; (II) seeds with approximately $5.9 \%$ of moisture content were stored in three different types of packages: a) permeable, b) semi-permeable and c) impermeable. Three storing conditions were tested: a) room temperature and $\mathrm{RH}$ under laboratory conditions; b) $15^{\circ} \mathrm{C}$ and $45 \%$ $\mathrm{RH}$; c) $20^{\circ} \mathrm{C}$ and $55 \% \mathrm{RH}$. Water content, germination rate and germination speed index were evaluated at 0, 4, 8 and 12 months of storing. The best germination results were obtained with the moisture range of $6.0 \leq 8.0 \%$, with seeds kept at room temperature; while the seeds stored at $10^{\circ} \mathrm{C}$, regardless the moisture range, did not survive. The stored seeds with $5.9 \%$ moisture content and at both $15^{\circ} \mathrm{C} / 45 \% \mathrm{RH}$ and $20^{\circ} \mathrm{C} / 55 \% \mathrm{RH}$ conditions, independently of the package type used, showed the best results. Thus, macaw palm seeds can be classified as intermediates seeds.

Key words: Acrocomia aculeata, recalcitrant, orthodox.

RESUMO

Considerando o grande potencial oleaginoso da macauba e a sua aplicabilidade nos setores energéticos e industriais, torna-se indispensável o conhecimento das condições adequadas de armazenamento das sementes, garantindo a manutenção da viabilidade. $O$ objetivo do trabalho foi avaliar o efeito do teor de água da semente e das condições de armazenamento (temperatura, umidade relativa do ar $e$ embalagem) sobre a qualidade das sementes, oriundas de Minas Gerais, durante 12 meses. O experimento foi realizado através de dois ensaios: no primeiro, as sementes foram armazenadas sob três faixas de umidade, 4,0 $6,0 \% ; 6,0 \leq 8,0 \%$ e $8,0 \leq 10,0 \%$, em embalagens impermeáveis, em temperatura ambiente e a $10^{\circ} \mathrm{C}$. No segundo, as sementes foram acondicionadas em três tipos de embalagem: a) permeável; b) semipermeável; e c) impermeável. Foram comparadas três condições de armazenamento: a) temperatura e UR ambientes, em condição de laboratório; b) $15^{\circ} \mathrm{C}$ e $45 \%$ UR; c) $20^{\circ} \mathrm{C}$ e $55 \%$ UR. Avaliou-se o teor de água, a taxa de germinação e o índice de velocidade de germinação aos 0, 4, 8 e 12 meses de armazenamento. A faixa de umidade de $6,0 \leq 8,0 \%$ em temperatura ambiente possibilitou a melhor conservação das sementes durante os 12 meses de armazenamento. Porém, as sementes não sobreviveram em temperatura de $10^{\circ} \mathrm{C}$, independente dos teores de umidade. O teor de água de 5,9\% e os ambientes de armazenamento de $15^{\circ} \mathrm{C} / 45 \%$ UR e $20^{\circ} \mathrm{C} / 55 \%$ UR, independente do tipo de embalagem, apresentaram os melhores resultados ao longo do armazenamento. Dessa forma, as sementes de macauba podem ser classificadas como sementes intermediárias.

Palavras-chave: Acrocomia aculeata, recalcitrante, ortodoxa

\section{INTRODUCTION}

The macauba (macaw palm), Acrocomia aculeata (Jacq.) Lodd. ex Martius, is a native

\footnotetext{
IDepartamento de Fitotecnia, Universidade Federal de Viçosa (UFV), Campus Viçosa, 36570-00, Viçosa, MG, Brasil. E-mail: naomikuki@hotmail.com. ${ }^{*}$ Corresponding author.

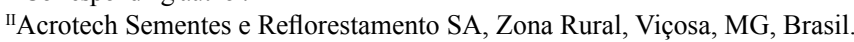

IIIDepartamento de Engenharia Florestal, Universidade Federal de Viçosa (UFV), Campus Viçosa, MG, Brasil. Received 06.12.15 Approved 06.13.16 Returned by the author 09.06.16 CR-2015-0848.R3
} 
palm tree of the Tropical America (CLEMENT et al., 2005). In Brazil, the palm is widely present in Minas Gerais State, populating areas of cerrado and semi-deciduous forest (MOTTA et al., 2002). The species has a great potential for the industry and as an alternative crop due to its high productivity and oil yield (MOTOIKE \& KUKI, 2009; LORENZI et al., 2011). The oil from the mesocarp shows suitable characteristics as feedstock for automotive and aviation biofuel industry (LANES et al., 2014).

Although macauba is considered a promising source of raw material for biofuel production, commercial-scale cultivation of the palm is nonexistent due to seed dormancy (RIBEIRO et al., 2011), which was an obstacle for seedlings production until 2007. Seed dormancy was overcome by a germination induction technique developed at the Universidade Federal de Viçosa (MOTOIKE et al., 2007). However, several studies including those related to seed storage remain uncovered. Establishing the best conditions for seed storage can meet the off-season production, since the fruiting of macauba is a long term process and marked by seasonality (LORENZI, 2006).

Artificial conditions influence seeds viability by interfering directly with their physiology. A major factor is the control of moisture content of the stored seeds. Once moisture content of seed is reduced to certain levels, seed decay rate decreases and the longevity increases (GARCIA et al., 2004). Temperature and relative humidity are other important factors in seed conservation. In general, lower temperatures and reduced atmospheric humidity ensure longevity of seeds by reducing their metabolic activity (HONG \& ELLIS, 1996). However, the susceptibility of seeds to temperature and dehydration will depend upon species.

According to their physiological response to storage conditions, seeds are classified as: (i) Orthodox - are those resistant to dehydration, with moisture content between 2.0 and $6.0 \%$, tolerant to temperatures below zero, and retaining longevity during storage; (ii) Recalcitrant - are those sensitive to dehydration and low temperatures and showing shorten longevity; (iii) Intermediate - are those tolerant to dehydration, with moisture content between 7.0 and $10.0 \%$, but sensitive to temperatures below $10^{\circ} \mathrm{C}$ (HONG \& ELLIS, 1996). RIBEIRO et al. (2012), based on the in vitro viability of zygotic embryos from stored fruit, suggested that macauba seeds showed orthodox behavior. However, the real nature of the seed response to storage conditions is still unknown.

Information about proper storage conditions for macauba seed is important but lacking in the literature. Therefore, this study aimed to examine the effect of seed moisture content and storage conditions (temperature, relative humidity and packaging) in the physiological quality of macauba seeds stored over a period of 12 months.

\section{MATERIALS AND METHODS}

The macauba seeds used in the study were harvested from natural populations growing in the state of Minas Gerais. Two independent assays were carried out:

Assay I. Effect of seed moisture and storage temperature on physiological quality of the seed

Mature fruits were collected in the municipality of Luz/Minas Gerais (19०48' $3^{\prime}$ ' S, 45 4' 9 " W), a region of tropical climate with dry summers (Aw-Köppen classification). Fruits were dried under shade and at room temperature for approximately 30 days. Then, the seeds were extracted from the endocarp with a mechanical clamp. To obtain uniform seed lots with three different moisture contents/ranges of $4.0 \leq 6.0 \%, 6.0 \leq 8.0 \%$ and $8.0 \leq 10.0 \%$, seeds were dried at $30^{\circ} \mathrm{C}$, in forced ventilation oven. The desired moisture content was obtained by monitoring the samples' weight difference (BRASIL, 2009). During the drying process, seeds were weighted at one-hour intervals until they reach the intended moisture. At the end of the process, the seeds were treated with fungicide Derosal ${ }^{\circledR}\left(3 \mathrm{~mL} \mathrm{~kg} \mathrm{~kg}^{-1}\right.$ seed), packed in impermeable aluminum foil bags and stored either at room temperature (laboratory conditions) or in BOD chamber at constant $10^{\circ} \mathrm{C}$.

Seed moisture content and germination were evaluated at $0,4,8$, and 12 months of storage. Moisture was measured by the incubator method, placing the seeds at $105^{\circ} \mathrm{C}$ for 24 hours (BRASIL, 2009). The procedure was carried out with four replicates, each composed of eight seeds. For the germination test, seeds were first subjected to the protocol developed by MOTOIKE et al. (2007) to overcome dormancy. Afterwards, they were sown in plastic boxes containing moistened germitest ${ }^{\circledR}$ paper and kept at $28^{\circ} \mathrm{C}$ in the dark. Seeds were considered germinated when radicle length had at least $4 \mathrm{~mm}$. For this test, four samples of 50 seeds/each were used. Data recording started at 14 days and extended until 30 days after sowing.

Assay II. Effect of package type and storage conditions on seed viability and vigor

Mature fruits were collected in the municipality of Santa Luzia/Minas Gerais (19 ${ }^{\circ} 46^{\prime}$ 
12 " $\mathrm{S}, 43^{\circ} 51^{\prime} 2$ " W), a region of humid subtropical climate (Cwa-Köppen classification). Seeds extraction and preparation followed the method described in the previous assay. By drying the seeds at constant $30^{\circ} \mathrm{C}$, moisture was standardized at a range of $4.0 \leq 6.0 \%(\sim 5.9 \%)$. Then, seeds were placed in three types of packages: a) permeable (Kraft paper bag); b) semi-permeable (polyethylene bag) and c) impermeable (flexible aluminum foil bag). Packages were placed in three experimental storage conditions: i) room temperature and relative humidity $(\mathrm{RH})$, under laboratory conditions; ii) $15^{\circ} \mathrm{C}$ and $45 \% \mathrm{RH}$ and iii) $20^{\circ} \mathrm{C}$ and $55 \% \mathrm{RH}$. At $0,4,8,12$ months of storage, seed moisture content, seed germination (as described in assay I) and germination speed index (GSI) were evaluated. The GSI was calculated on a daily basis using the number of germinated seeds (MAGUIRE, 1962). The data recording started at 14 days and extended until 30 days after the sowing.

\section{Statistical design and analysis}

The experiment on assay I was set in a completely randomized design, in a factorial $3 \times 2 \times 4$ (3 seed moisture ranges, 2 storage temperature and 4 storage periods), with four replicates of 58 seeds per treatment. The experiment on assay II was also set in a completely randomized design, in a factorial $3 \times 3 \times 4$ (3 types of packages, 3 storage conditions and 4 storage periods), with four replicates of 58 seeds per treatment. Data were subjected to analysis of variance using the F test. The Tukey's test at 5\% significance was used to compare the treatment means.

\section{RESULTS}

Assay I

During the 12-month storage period seeds preserved their moisture content within the previously established ranges. However, seeds kept at $10^{\circ} \mathrm{C}$, from the fourth month onwards, lost their germination capacity regardless of their moisture content. Those seeds were thus excluded from the experiment. In contrast, the seeds stored at room temperature retained viability regardless of their moisture content but, as storage period progressed, their ability to germinate declined. This decrease was more evident for the seeds with $8.0 \leq 10.0 \%$ of moisture, followed by seeds with $4.0 \leq 6.0 \%$ and $6.0 \leq 8.0 \%$ of moisture (Figure 1A).

Assay II

Analysis of variance for the seed moisture content showed a significant interaction between the storage period $v s$ package type and between storage conditions $v s$ package type. For the interaction storage period vs package type, seeds kept in the impermeable package had lower variation in moisture content. Their moisture was preserved within the original values of $4.0 \leq 6.0 \%$ (Figure $1 \mathrm{~B}$ ). For the interaction storage condition vs package type, there was a reduction in moisture content when the seed were kept in both permeable and semipermeable packages and placed under $20^{\circ} \mathrm{C} / 55 \% \mathrm{RH}$ and $15^{\circ} \mathrm{C} / 45 \% \mathrm{RH}$. However, the seeds in impermeable packages showed no significant change in moisture content (Table 1).

Analysis of variance of germination and GSI did not show interaction between the studied factors. However, storage period and storage conditions individually presented significant effect on germination and GSI. Both variables increased linearly during storage (Figure 1C, D). The germination percentage of seeds stored under controlled environment was higher than those kept in non-controlled condition (room temperature and $\mathrm{RH}$ ). The storage condition of $20^{\circ} \mathrm{C} / 55 \% \mathrm{RH}$ allowed the best seed conservation, depicted by a higher germination rate and greater GSI (Table 2).

\section{DISCUSSION}

Macauba seeds showed tolerance to desiccation but were susceptible to low temperature. Similar results were observed for two other palm species, Elaeis guineensis (ELLIS et al., 1991) and Phoenix reclinata (FINTEL et al., 2004). Thus macauba seeds can be classified as intermediate in relation to its physiological response to storage conditions (HONG \& ELLIS, 1996). This fact opposes to RIBEIRO et al. (2012) who reported an orthodox behavior for the species, during an in vitro investigation. However, the population studied by RIBEIRO et al. (2012) was from a cerrado-caatinga region whereas the seeds of the present study were from a semi-deciduous forest region. Morphoclimatic factors are selection pressures that drive the pattern of plant responses, including adjustment in germination response, which guarantees success in the prevailing environmental conditions (TEKRONY, 2003). Therefore, the response of macauba seeds to the storage conditions may be related to their provenance, since seeds incorporate the genetic and the environmental components in their development (QUN et al., 2007). BERTON et al. (2013) reported wide variation in the percentage of germination and GSI of macauba seeds and attributed these differences to the genetic background of the studied populations.

The viability of macauba seeds was preserved during the 12-months storage period, 


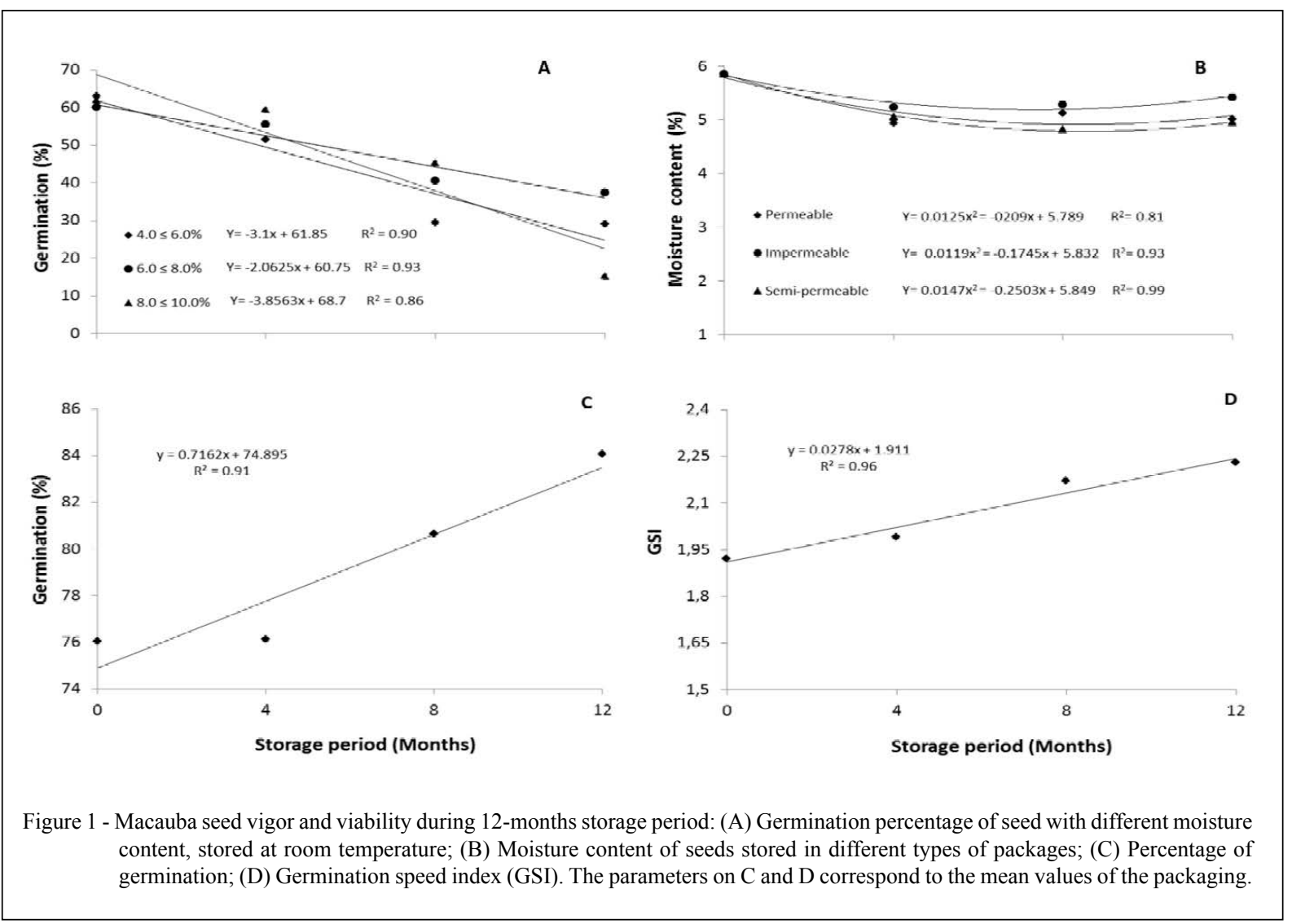

regardless of the package type used. This fact shows that the control of the environmental conditions alone is effective in maintaining the seed quality. The best storage condition to store the seeds was $20^{\circ} \mathrm{C} / 55 \% \mathrm{RH}$ (Table 2), revealing that simultaneous low temperature and low RH promotes seed longevity, especially when the seed's moisture content has been previously reduced. Under such circumstances the metabolic activity of seed greatly decreases. Therefore, an adequate dehydration of the seeds is the first requirement for long-term storage (PRITCHARD et al., 2004). Lastly, it is recommended to control the temperature and relative humidity of the storage environment in order to maintain the physiological quality of the seed (CARVALHO \& NAKAGAWA, 2000).

Small variations in seed moisture content, especially when macauba seeds were kept in permeable and semi-permeable bags, may be related to the porosity of the packages and storage conditions, as seeds tend to a hygroscopic equilibrium with the environment (CARVALHO \& NAKAGAWA, 2000; BEWLEY et al., 2013). Even when macauba seeds were still

Table 1 - Moisture content (\%) of macauba seeds stored in different conditions and packages.

\begin{tabular}{lccc}
\hline Storage condition & Permeable & Impermeable & Semi-permeable \\
\hline room ${ }^{\circ} \mathrm{C} / \mathrm{RH}$ & $5.9^{\mathrm{Aa}}$ & $5.3^{\mathrm{Ac}}$ & $5.6^{\mathrm{Ab}}$ \\
$15^{\circ} \mathrm{C} / 45 \% \mathrm{RH}$ & $4.6^{\mathrm{Bb}}$ & $5.2^{\mathrm{Aa}}$ & $4.5^{\mathrm{Bb}}$ \\
$20^{\circ} \mathrm{C} / 55 \% \mathrm{RH}$ & $4.6^{\mathrm{Bb}}$ & $5.4^{\mathrm{Aa}}$ & $4.7^{\mathrm{Bb}}$ \\
\hline
\end{tabular}

The means followed by the same capital letter in the column and small letter on the line do not differ statistically by the Tukey test at $5 \%$ probability.

Ciência Rural, v.46, n.11, nov, 2016. 
Table 2 - Germination and germination speed index (GSI) of macauba seeds stored under different temperatures and relative humidity $(\mathrm{RH})$.

\begin{tabular}{lcl}
\hline Storage condition & Germination $(\%)$ & GSI \\
\hline room ${ }^{\circ} \mathrm{C} / \mathrm{RH}$ & $77.28^{\mathrm{b}}$ & $2.02^{\mathrm{b}}$ \\
$15^{\circ} \mathrm{C} / 45 \% \mathrm{RH}$ & $80.83^{\mathrm{a}}$ & $2.14^{\mathrm{ab}}$ \\
$20^{\circ} \mathrm{C} / 55 \% \mathrm{RH}$ & $82.66^{\mathrm{a}}$ & $2.23^{\mathrm{a}}$ \\
\hline
\end{tabular}

The means followed by the same letter in the column do not differ statistically by the Tukey test at $5 \%$ probability.

protected by the fruit layers, their moisture content varied (RIBEIRO et al., 2012). In oleaginous seeds, the variation in moisture content correlates directly with the amount of stored lipids. Considering that macauba seeds have a high oil content (HIANE et al., 2005), reduction in seed moisture content are the most suitable method to assure a proper storage (VERTUCCI \& ROOS, 1990). Failure in this step can increase the degradation rate of storage reserves in seeds and diminish their physiological quality during storage (WALTERS, 1998).

The increase in macauba seed germination and GSI values, along with the storage period, may be related to the overcoming of dormancy. Similar results were also reported for other palm species such as Chamaerops humilis (GONZÁLEZ-BENITO et al., 2006), Syagrus flexuosa and $S$. yungasensis (PRITCHARD et al., 2004). Although the macauba seeds were previously treated to stimulate germination, the extended storage period and the proper conditions in which they were kept may have enhanced their germination response.

Macauba seeds with same moisture content of $4.0 \leq 6.0 \%$, displayed contrasting germination response in assay I (decreased germination) and assay II (increased germination). This phenomenon may be related to the seeds provenances: in the first assay the seeds were from a region with Aw climate whereas seeds in the second assay were from a region with Cwa climate. Each donor population probably suffered different environmental pressures resulting in genetic variability, which reflected in seed germination response. According to BERTON et al. (2013) the broad geographical distribution of the macauba is possibly influenced by the species genetic plasticity regarding germination characteristics. This trait would enable the seeds to cope with different and changing environmental conditions. However, more detailed studies are necessary.

\section{CONCLUSION}

The viability of the macauba seeds is affected by storage temperature and seed moisture content. The moisture content of $6.0 \leq 8.0 \%$ allows the best seed conservation. The storage temperature of $10^{\circ} \mathrm{C}$ is detrimental for seed viability. However the macauba seed presents desiccation tolerance; therefore, it can be classified as intermediate type.

\section{ACKNOWLEDGEMENTS}

The authors would to thank the Universidade Federal de Viçosa for the academic opportunity; Acrotech SA and FAPEMIG/Vale (grant \# CAG/MOP 0017610) for the logistic and financial support; The Conselho Nacional de Desenvolvimento Científico e Tecnológico (CNPq) and Comissão de Aperfeiçoamento de Pessoal do Nível Superior (CAPES) for the scholarships; and Professor Roberto Ferreira da Silva for the valuable suggestions.

\section{REFERENCES}

BERTON, L.H.C. et al. Seed germination and estimates of genetic parameters of promising macaw palm (Acrocomia aculeata) progenies for biofuel production. Industrial Crops and Products, v.51, p.258-266, 2013. Available from: <http://www.sciencedirect.com/science/article/pii/ S0926669013005098>. Accessed: Jul. 21, 2016. doi: 10.1016/j. indcrop.2013.09.012.

BEWLEY, J.D. et al. Physiology of development, germination and dormancy. 3. ed. New York: Springer, 2013. 392p.

BRASIL. Ministério da Agricultura, Pecuária e Abastecimento. Regras para análise de sementes. Ministério da Agricultura, Pecuária e Abastecimento. Secretaria de Defesa Agropecuária. Brasília, DF: Mapa/ACS, 2009. p.395. Available from: <http:// www.agricultura.gov.br/arq_editor/file/2946_regras_analise_ sementes.pdf>. Accessed: Nov. 08, 2014.

CARVALHO, N.M.; NAKAGAWA, J. Sementes: ciência, tecnologia e produção. Jaboticabal: FUNEP, 2000. 588p.

CLEMENT, C.R. et al. O potencial das palmeiras tropicais no Brasil: acertos e fracassos das últimas décadas. Agrociências, v.9, p.67-71, 2005. Available from: <http://www.fagro.edu. uy/ agrociencia/index.php/directorio/article/view/279/209>. Accessed: Jul. 21, 2016.

ELLIS, R.H. et al. Seed storage behaviour in Elaeis guineensis. Seed Science Research, v.1, p. 99-104, 1991. doi: 10.1017/ S0960258500000726.

FINTEL, G.T. et al. Seed behaviour in Phoenix reclinata Jacquin, the wild date palm. Seed Science Research, v.14, p.197-204, 2004. Available from: <https:/www.researchgate.net/ publication/231798068>. Accessed: Jul. 21, 2016. doi: 10.1079/ SSR2004169.

GARCIA, D.C. et al. A secagem de sementes. Ciência Rural, v.34, n.2, p.603-608, 2004. Available from: <http://www.redalyc.org/ pdf/331/33134245.pdf>. Accessed: Nov. 08, 2014. 
GONZÁLEZ-BENITO, M.E. et al. Seed germination and storage of Chamaerops humilis (Dwarf Fan Palm). Seed Science \& Technology, v.34, p.143-150, 2006. Available from: $<$ https://www. researchgate.net/publication/233584564>. Accessed: Jul. 21, 2016. doi: $10.15258 /$ sst.2006.34.1.15.

HIANE, P.A. et al. Bocaiúva, Acrocomia aculeata (Jacq.) Lodd., pulp and kernel oils: Characterization and fatty acid composition. Brazilian Journal of Food Technology, v.8, n.3, p.256-259, 2005. Available from: <http://bjft.ital.sp.gov.br/artigos/html/busca/PDF/ v8n3212a.pdf $>$. Accessed: Nov. 08, 2014.

HONG, T.D.; ELLIS, R.H. A protocol to determine seed storage behaviour. Rome, Italy: International Plant Genetic Resources Institute, 1996. 62p. (IPGRI Technical Bulletin, 1). Available from: $<$ http://cropgenebank.sgrp.cgiar.org/images/file/learning_space/ technicalbulletin1.pdf>. Accessed: Nov. 08, 2014.

LANES, E.C.M. Alternative fuels: Brazil promotes aviation biofuels. Nature, v.511, n.31, 2014. Available from: <http:// www.nature.com/nature/journal/v511/n7507/full/511031a.html >. Accessed: Jul. 25, 2016. doi: 10.1038/511031a.

LORENZI, G.M.A.C. Acrocomia aculeata (Jacq.) Lodd. Ex. Mart. Arecaceae: bases para o extrativismo sustentável. 2006. 156f. Tese (Doutorado em Agronomia) - Curso de Pós-graduação em Agronomia, Universidade Federal do Paraná, PR.

LORENZI, G.M.A.C. et al. Prospecção da cadeia produtiva dos frutos da palmeira macauba no estado de Minas Gerais. Informe Agropecuário, v.32, n.265, p.7-14, 2011.

MAGUIRE, J.D. Speed of germination-aid in selection and evaluation for seedling emergence and vigor. Crop Science, v.2, n.1, p.176-177, 1962.

MOTOIKE, S.Y. et al. Processo de germinação e produção de sementes pré-germinadas de palmeiras do gênero Acrocomia. 2007. Patente: Privilégio de Inovação. n. PI0703180-7, "Processo". 20 jul. 2007 (Depósito).

MOTOIKE, S.Y.; KUKI, K.N. The potential of macaw palm (Acrocomia aculeata) as source of biodiesel in Brazil. Ireche, v.1, n.6, p.632-635, 2009.
MOTTA, P.E.F. et al. Ocorrência da macauba em Minas Gerais: relações com atributos climáticos, pedológicos e vegetacionais. Pesquisa Agropecuária Brasileira, v.37, p.10231031, 2002. Available from: <http://www.scielo.br/pdf/pab/ v37n7/10807.pdf>. Accessed: Jul. 21, 2016. doi: 10.1590/S0100204X2002000700017.

PRITCHARD, H.W. et al. 100-seed test for desiccation tolerance and germination: a case study on eight tropical palm species. Seed Science \& Technology, v.32, p.393-403, 2004. Available from: $<$ http://www.academia.edu/17399366>. Accessed: Jul. 25, 2016. doi: $10.15258 /$ sst.2004.32.2.11.

QUN, S. et al. Advances on seed vigor physiological and genetic mechanisms. Agricultural Sciences in China, v.6, n.9, p.1060-1066, 2007. Available from: <http://ac.els-cdn.com/ S1671292707601473/1-s2.0-S1671292707601473-main.pdf>. Accessed: Jul. 21, 2016. doi: 10.1016/S1671-2927(07)60147-3.

RIBEIRO, L.M. et al. Overcoming dormancy in macaw palm diaspores, a tropical species with potential for use as bio-fuel. Seed Science and Technology, v.39, p.303-317, 2011. Available from: <http://www.academia.edu/755072>. Accessed: Sept. 16, 2014.

RIBEIRO, L.M. et al. The behavior of macaw palm (Acrocomia aculeata) seeds during storage. Seed Science \& Technology, v.40, p.1-10, 2012. Available from: <http://www.academia. edu/2238176>. Accessed: Nov. 08, 2014.

TEKRONY, D.M. Precision is an essential component in seed vigour testing. Seed Science \& Technology, v.31, n.2, p.435-447, 2003.

VERTUCCI, C.W.; ROOS, E.E. Theoretical basis of protocols for seed storage. Plant Physiology, v.94, p.1019-1023, 1990. Available from: <http://www.ncbi.nlm.nih.gov/pmc/articles/ PMC1077336/pdf/plntphys00812-177.pdf>. Accessed: Nov. 08, 2014. doi: 10.1104/pp.94.3.1019.

WALTERS, C. Understanding the mechanisms and kinetics of seed aging. Seed Science Research, v.8, p.223-244, 1998. 